\title{
Insect Pests in England and Wales*
}

$\mathrm{A}$ RECENT official report on crop pests in England and Wales covers the years 1928-31 and forms Bulletin 66 (1933) of the Ministry of Agriculture and Fisheries. In this publication, Mr. J. C. F. Fryer, director of the Ministry's Plant Pathology Laboratory at Harpenden, reviews the general position over the period mentioned.

In methods of pest control, definite progress is evident with regard to enemies of fruit and other horticultural crops. The English grower to-day, provided he can achieve the desired result, adopts insecticidal measures on a scale as thorough as those employed in the Dominions and the United States. The progressive man realises that, to produce good sound marketable fruit, spraying is not merely an advantage, but is also an absolutely essential part of cultural routine.

In the use of dry sprays or dusts Great Britain is, however, a long way behind. It is nevertheless becoming recognised that they have definite ad vantages in point of ease and speed of application and reduced costs. Their adoption does not seem likely to come into practice until certain initial difficulties have been overcome. Many of the improvements in control measures have resulted from investigations carried out by members of the Research and Advisory Services of the Ministry of Agriculture. Now winter spray fluids have emanated from the Long Ashton Research Station.

Much work has been done in connexion with pyrethrum. It has been shown that this plant can be grown satisfactorily in many parts of Fngland. The problem as to whether the growing of the crops is an economic proposition is now being tried out. At Rothamsted, progress has been made in methods of evaluating the toxic principles found in the pyrethrum flowers. Also, experiments have been conducted with pyrethrum sprays in connexion with horticulture, which show promise, and there is little doubt that considerable developments in this direction are probable.

The entry of foreign pests through the agency of

* Ministry of Agriculture and Fisheries. Bulletin No. 66 : Report on Insect Pests of Crops in England and Wales, 1928-1931. Pp. vi +50. (London: H.M. Stationery Office, 1933.) 18. net. commerce, or other means, forms the second part of this Bulletin. During the period under review the apple fruit fly (Rhagoletis pomonella) was detected in consignments of low grade apples from the United States. Since it is a serious pest, likely to thrive under English conditions, the Ministry issued the Importation of Apples Order 1930 entirely prohibiting the entry of certain grades of apples from the United States within a specified period each year. Among other immigrant pests the cherry fruit fly, chrysanthemum midge and cottony cushion scale are briefly noticed. Reference is also made to an introduced insect of a beneficial character, namely, the chalcid wasp Aphelinus mali. This insect has proved itself at times to be capable of controlling the woolly aphis under English conditions. Whether it is capable of persisting from year to year is very uncertain, and it appears to have failed in many cases owing to unfavourable climatic conditions. It is therefore still doubtful whether this useful parasite can be permanently acclimatised or whether it will need to be reintroduced every few years from colonies grown under protected conditions.

The major part of the Bulletin is devoted to a review of the prevalence of each specific crop pest during the four years under consideration. The attacks of cereal and grassland insects, for example, were, on the whole, below the average. Vegetable enemies, especially root flies, caused a good deal of destruction in various parts of the country but the most serious pests were those affecting orchards. Especially injurious were the apple capsid and the apple sawfly. Among strawberry pests the 'red spider' (Tetranychus telarius) was very destructive in 1929, when it appeared for the first time in epidemic form : in subsequent years it showed a marked decline. Mention needs also to be made of the great prevalence of the aphis, Myzus cerasi, on cherries in Kent which was a feature in 1928 : severe infestations also occurred in the south-west of England during 1931.

The Bulletin concludes with a useful list of papers published during 1928-31 in various jourmals and bearing upon subjects dealt with in its pages.

A. D. I.

\section{Petrogenesis of the Newry Igneous Complex}

$\mathrm{I}^{\mathrm{N}}$ her paper on "The Eastern End of the Newry Igneous Complex", which was read before the Geological Society on February 7, Miss Doris L. Reynolds made a contribution to petrogenesis of outstanding importance. The rocks described are types common to many orogenic regions, and include peridotite, biotite-pyroxenite, augite- and hypersthene-monzonite, augite-biotite-diorite and granodiorite. These are convincingly shown to be derivatives, not from basaltic or granitic magmas (gabbro and granite being absent from the area), but from three primary sources, two of which have hitherto remained unsuspected. The three parental materials now recognised are $(a)$ ultrabasic magmas rich in potash; (b) Silurian sediments which became fused by contact with the latter; (c) a magma represented almost entirely by plagioclase. The conclusions reached are supported by a suite of detailed analyses made by Mr. L. Theobald and Prof. H. F. Harwood.

The earliest intrusions were peridotite and biotite. pyroxenite, the latter representing a residual magma produced by the abstraction of early-formed olivine and pyroxene from peridotite magma. The ultrabasic magmas rose into graywackes and shales and bocame surrounded by a zone of selective fusion now represented by a fine-grained massive rock that is seen in all stages of development.

The ultrabasic magmas, which were too dense to rise by stoping, came into place partly by shouldering aside the enclosing sediments, as shown by the way in which the strike lines deviate from the regional Caledonian trend and curve round the contacts, and partly by soaking into the overlying zone of fusion, thus giving rise to augite-monzonite.

Simultaneously with, and also subsequent to, the 